\title{
From sugars to modified nucleosides
}

\author{
Eva Hýrošová, ${ }^{a}$ Lubor Fišera, ${ }^{\text {** }}$ Michal Medvecký, ${ }^{a}$ Hans-Ulrich Reissig, \\ Ahmed Al-Harrasi, ${ }^{b}$ and Miroslav Koóš ${ }^{c}$ \\ ${ }^{a}$ Institute of Organic Chemistry, Catalysis and Petrochemistry, Slovak University of Technology, \\ SK-812 37 Bratislava, Slovak Republic \\ ${ }^{b}$ Institut für Chemie und Biochemie, Freie Universität Berlin, Takustr. 3, 14195 Berlin, Germany \\ ${ }^{c}$ Institute of Chemistry, Slovak Academy of Sciences, 84538 Bratislava, Slovak Republic \\ E-mail: lubor.fisera@stuba.sk
}

\begin{abstract}
Two strategies are reported for the diastereoselective synthesis of isoxazolidinyl nucleosides, as potential antiviral agents - a one-step approach based on 1,3-dipolar cycloaddition of sugarderived nitrones with vinyl nucleobases derived from uracil and adenine, as well as a two-step methodology based on the Vorbrüggen nucleosidation of the 5-acetoxyisoxazolidines. The 1,3dipolar cycloadditions of sugar-derived nitrones with vinyl acetate proceed with very good diastereoselectivity to give the diastereoisomeric isoxazolidines. Condensation of the major diastereomerically pure acetoxyisoxazolidines with silylated uracil, thymine, cytosine, $\mathrm{N}$ acetylguanine and purines occurs with moderate to excellent stereoselectivity with the formation of the expected isoxazolidinyl nucleosides. The stereoselectivity of the addition of the silylated nucleobase is dependent on the structure of the substituent at C-3 originating from the starting chiral nitrone and on the attacking nucleobase.
\end{abstract}

Keywords: Nucleosides, 1,3-dipolar cycloadditions, chiral nitrones, carbohydrates, isoxazolidines, stereoselectivity

\section{Contents}

1. Introduction

2. Sugar-derived Nitrones

3. Isoxazolidinyl Nucleosides

3.1. From D-glycero nitrone and vinylthymine

3.2. From D-xylo nitrones and vinyluracil and vinyladenine

3.3. From D-lyxo nitrone and vinyladenine

4. Acetoxyisoxazolidines prepared from Sugar-derived Nitrones 
4.1. 1,3-Dipolar cycloaddition of D-glycero nitrone with vinyl acetate

4.2. 1,3-Dipolar cycloaddition of sugar- derived nitrones $\mathbf{2 - 8}$ with vinyl acetate

5. Isoxazolidinyl Nucleosides prepared by Vorbrüggen Nucleosidation

5.1. Isoxazolidinyl nucleosides derived from D-glyceraldehyde

5.2. Isoxazolidinyl nucleosides derived from D-xylose

5.3. Isoxazolidinyl nucleosides derived from D-lyxose

5.4. Isoxazolidinyl nucleosides derived from D-erythrose

5.5. Isoxazolidinyl nucleosides derived from D-threose

5.6. Isoxazolidinyl nucleosides prepared from D-iso-ascorbic acid

5.7. Isoxazolidinyl nucleosides derived from L-threose

5.8. Isoxazolidinyl nucleosides prepared from D-mannitol

6. Conclusions

\section{Introduction}

Nitrogen-containing heterocycles and their derivatives have broad application in synthetic materials, and biological chemistry and, as a result, their synthesis and reactivity is subject of considerable interest. Over the years, nitrones have become important building blocks in organic synthesis. ${ }^{1-10}$ Nucleosides are generally defined as DNA or RNA subunits and consist of both a base moiety such as adenine, thymine, guanine, cytosine and uracil, and a sugar moiety such as D-ribose or 2-deoxy-D-ribose. ${ }^{11}$ Many nucleoside analogues have been synthesized with modification of the base, sugar, and phosphate moieties. In particular, nucleoside analogues in which the furanose ring has been replaced by different carbon or heterocyclic systems, have attracted special interest by virtue of their biological action as antiviral and/or anti-cancer agents. ${ }^{12}$ Among these, the uracil-, thymine-, cytosine-, and adenine- nucleosides 1 possessing an isoxazolidinyl moiety (carbocyclic-2'-oxo-3'-azanucleosides) are emerging as an interesting class of dideoxynucleoside analogues with potential pharmacological activity. ${ }^{12}$ For the synthesis of modified isoxazolidinyl nucleosides 1 two strategies can be used - in particular, a one-step approach based on the 1,3-dipolar cycloaddition of nitrones with vinyl nucleobases, and a twostep methodology based on the Vorbrüggen nucleosidation of 5-acetoxyisoxazolidines. ${ }^{13-20}$<smiles>[R]C1C[C@@H]([B])ON1Cc1ccccc1</smiles>

1

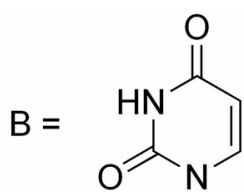<smiles></smiles><smiles></smiles><smiles>Nc1ncnc2[nH]cnc12</smiles>

\section{Figure 1}




\section{Sugar-derived Nitrones}

Glycosides are important as enzyme inhibitors, and as chiral synthons suitable for the synthesis of many natural products. Since the 1,3-dipolar cycloaddition has a nearly singular capability of establishing large numbers of stereogenic centers in one synthetic step in recent years attention has been focused on the preparation of chiral sugar- derived nitrones. The configuration of the newly generated stereogenic centers would be determined by the nitrone. Asymmetric induction in 1,3-dipolar cycloaddition has been achieved efficiently by using nitrones with chiral groups at either the nitrogen atom or the carbon atom. ${ }^{4}$ Among nitrones, the sugar- derived nitrones represent versatile substrates as they provide a polyhydroxylated carbon framework with multiple avenues of chirality. ${ }^{9}$ During recent years we have gained knowledge of the preparation of optically active nitrone templates for the asymmetric 1,3-dipolar cycloadditions and samarium diiodide- induced couplings. ${ }^{21-27}$ In connection with our synthetic studies on the utility of chiral nitrones for the synthesis of biologically interesting compounds, we have prepared the sugarderived nitrones 2-8 possessing structures suitable for building nitrogen-containing heterocycles (Scheme 1).

The aim of the present account is to describe the diastereoselective synthesis of isoxazolidinyl nucleosides by means of a 1,3-dipolar cycloaddition of chiral sugar- derived nitrones as the key step. The use of $C$-chiral nitrones allows diastereoselective synthetic access to homochiral isoxazolidinyl nucleosides. The enantioselective synthesis of isoxazolidinyl nucleosides by using chiral $\mathrm{N}$-glycosyl nitrones is not included in this account. ${ }^{15,20,28}$

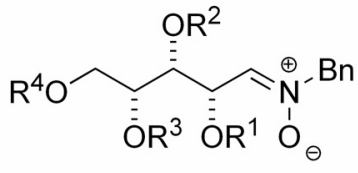

2

a $\mathrm{R}^{1}, \mathrm{R}^{2}=\mathrm{R}^{3}, \mathrm{R}^{4}=\mathrm{CMe}_{2}$

b $R^{1}, R^{2}=\mathrm{CMe}_{2}, \mathrm{R}^{3}=\mathrm{Bz}, \mathrm{R}^{4}=$ TBDPS

c $R^{1}, R^{2}=\mathrm{CMe}_{2}, \mathrm{R}^{3}=\mathrm{Bn}, \mathrm{R}^{4}=$ TBDPS

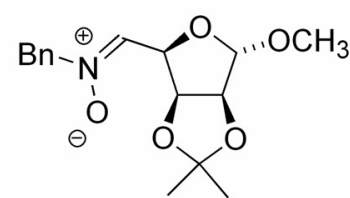

3

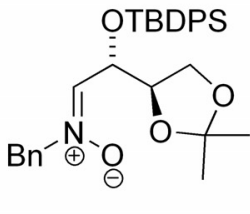

6

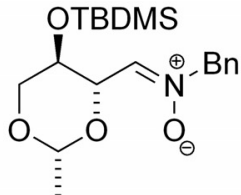

4

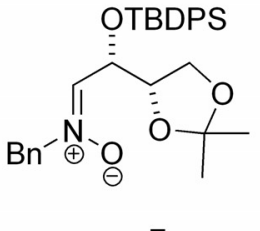

7

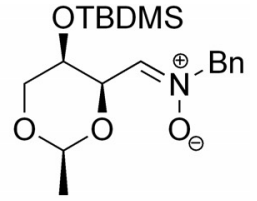

5

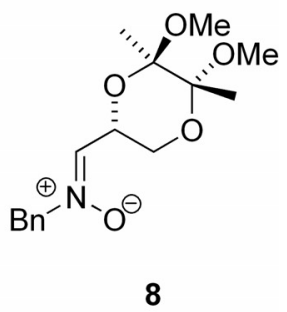

\section{Scheme 1}




\section{Isoxazolidinyl Nucleosides}

For the synthesis of modified isoxazolidinyl nucleosides 1, two strategies can be used: a one-step approach based on the 1,3-dipolar cycloaddition of nitrones with vinyl nucleobases, and a twostep methodology based on the Vorbrüggen nucleosidation of 5-acetoxyisoxazolidines (Scheme 2). ${ }^{15-20}$
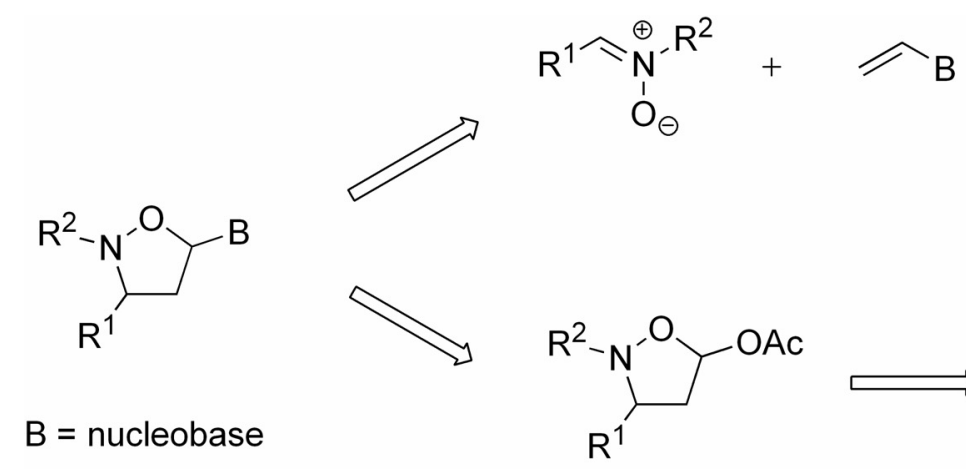

\section{Scheme 2}

\subsection{From D-glycero nitrone and vinylthymine}

The 1,3-dipolar cycloaddition between an achiral nitrone and a vinyl base has been applied to the synthesis of isoxazolidinyl nucleosides. ${ }^{19,29-31}$ This approach should be a highly promising reaction for the straightforward synthesis of a variety of isoxazolidinyl nucleosides. The first chiral version of that reaction has been investigated by Merino. ${ }^{16}$ The cycloaddition of the nitrone 9, which is readily available from 2,3-O-isopropylidene-D-glyceraldehyde, with vinylthymine (10) in refluxing toluene proceeded smoothly to give a 73:18:9 mixture of three adducts 11-13 in 88\% yield (Scheme 3). Deprotection of the separated anomers was achieved by using catalytic $p$-TsOH in $\mathrm{MeOH}$. The resulting 1,2-diols were treated sequentially with sodium periodate and sodium borohydride to give the hydroxymethyl- substituted isoxazolidinyl nucleosides 14-16 in good yields.

\subsection{From D-xylo nitrones and vinyluracil and vinyladenine}

We have prepared from D-xylose the new sugar-derived nitrones $\mathbf{2 a}$ and $\mathbf{2} \mathbf{b}$ possessing structures suitable for the building of pyrrolidines. ${ }^{32}$ Their cycloadditions to vinylated nucleobases $\mathbf{1 7}$, derived from uracil and adenine, proceeded regioselectively and led to the isoxazolidines 18-20 as a mixture of four diastereoisomers in all cases (Scheme 4). In the case of cycloadditions of nitrones $\mathbf{2 a}$ and $\mathbf{2 b}$ with 9-vinyladenine $\mathbf{1 7} \mathbf{b}$ an inseparable mixture of the adenosine diastereoisomers has been obtained. To improve the separation the free amino group of the adenine moiety was protected. The cycloaddition of nitrone 2a with $\mathrm{N}, \mathrm{N}$-dimesylated 9vinyladenine $\mathbf{1 7 b}$ proceeded with better selectivity, in favor of the major anti-cis isomer 20a. ${ }^{32}$ 


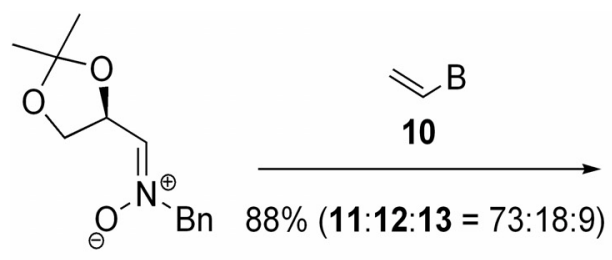

9<smiles>[B]C1CC([C@H]2COC(C)(C)O2)N(Cc2ccccc2)O1</smiles>

11<smiles>[B]C1CC([C@H]2COC(C)(C)O2)N(Cc2ccccc2)O1</smiles>

12<smiles>[B]C1C[C@@H](C2COC(C)(C)O2)N(Cc2ccccc2)O1</smiles>

13<smiles>[B]C1CC(CO)N(Cc2ccccc2)C1CO[NH3+]</smiles>

16

Scheme 3

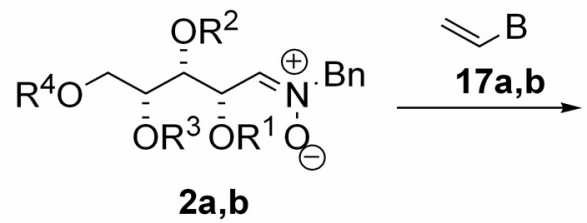

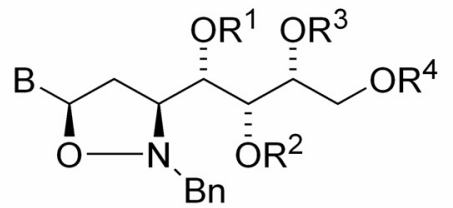

18a-20a<smiles>[R4]OC[C@H]([R2])[C@@H](O[R2])[C@H](O[R1])[C@H]1C[C@H]([B])ON1Cc1ccccc1</smiles>

18c-20c

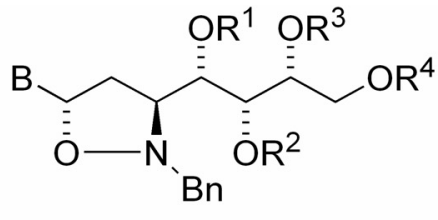

18b-20b

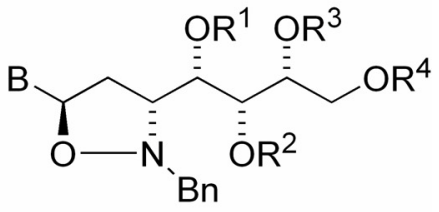

18d-20d

2a $R^{1}, R^{2}=R^{3}, R^{4}=C M e_{2}$

2b $R^{1}, R^{2}=\mathrm{CMe}_{2}, \mathrm{R}^{3}=\mathrm{Bz}, \mathrm{R}^{4}=\mathrm{TBDPS}$

$18 R^{1}, R^{2}=R^{3}, R^{4}=C M e_{2}, B=$ uracil 63:17:15:5

$19 \mathrm{R}^{1}, \mathrm{R}^{2}=\mathrm{CMe}_{2}, \mathrm{R}^{3}=\mathrm{Bz}, \mathrm{R}^{4}=$ TBDPS, $\mathrm{B}=$ uracil 59:24:11:16

$20 R^{1}, R^{2}=R^{3}, R^{4}=\mathrm{CMe}_{2}, B=$ adenine, 73:13:9:5<smiles></smiles>

a<smiles>CN(C)c1ncnc2[nH]cnc12</smiles>

b

\section{Scheme 4}

$\mathrm{X}$-ray analysis of the major diastereoisomer 18a prepared from uracil reveals a $\mathrm{C}-3 / \mathrm{C}-1$ ' antiand $\mathrm{C}-3 / \mathrm{C}-5$ cis- configuration, and therefore indicates that the cycloaddition arises from the more sterically accessible si face of the Z-nitrone $\mathbf{2 a}$, via an exo-transition state for the anti-cis diastereoisomer 18a and via an endo transition state for the anti-trans 19a isomer (Fig. 2). 


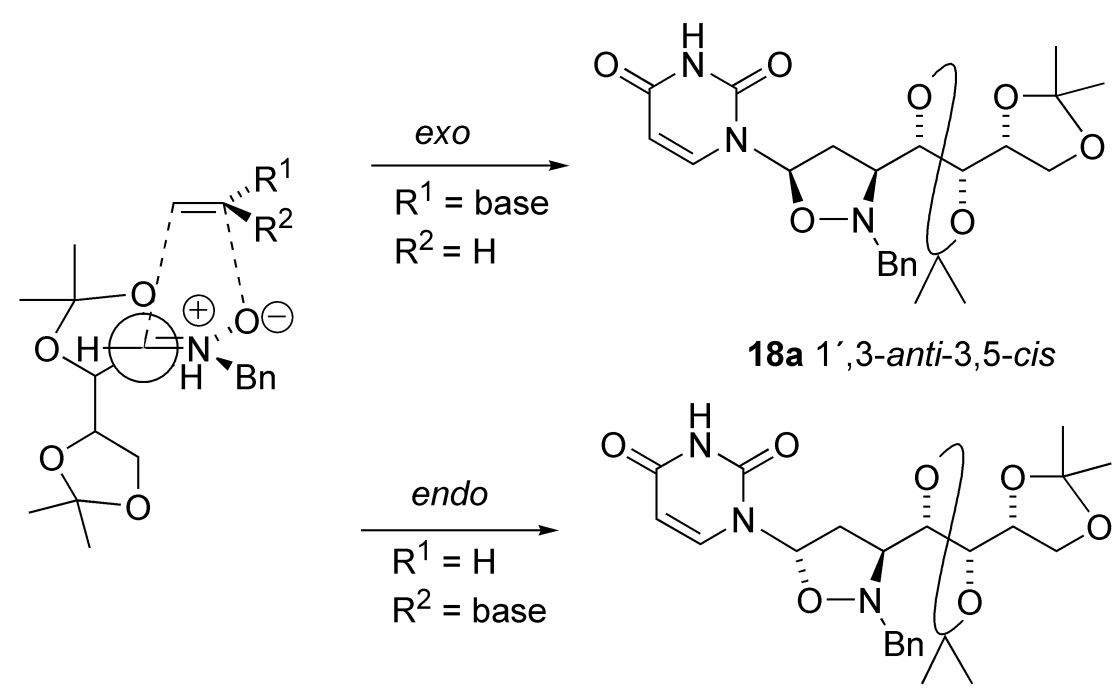

19a 1',3-anti-3,5-trans

\section{Figure 2}

\subsection{From D-lyxo nitrone and vinyladenine}

The 1,3-dipolar cycloaddition of the readily available chiral sugar- derived D-lyxosyl nitrone $\mathbf{3}$, with $N, N$-dibenzyl-9-vinyladenine has been also investigated in our group. ${ }^{33}$ Nitrone $\mathbf{3}$ reacted with $N, N$-dibenzyl-9-vinyladenine to give a mixture of all possible 5-substituted isoxazolidines 22-25 in the ratio of 39:27:19:15 in 98\% yield, the anti-cis isomer 22 being the major product (Scheme 5). Two of them, with a C-3/C-5 trans configuration of the isoxazolidine moiety, are $\alpha-$ anomers and the other two possess a $\mathrm{C}-3 / \mathrm{C}-5$ cis configuration of the isoxazolidine moiety are $\beta$ anomers. Whereas the regioselectivity of the reaction was very high, the corresponding 4substituted regioisomers were not detected, and both the cis/trans selectivity (cis/trans ratio 58:42) and the diastereofacial selectivity (anti/syn ratio 66:34) were rather low.

\section{Acetoxyisoxazolidines prepared from Sugar- derived Nitrones}

Since we found that the cycloadditions of chiral sugar- derived nitrones to vinylated nucleobases derived from uracil and adenine led to the isoxazolidines as a mixture of four diastereoisomers in all cases, for the synthesis of modified isoxazolidinyl nucleosides we have chosen a two-step methodology based on the Vorbrüggen nucleosidation of the 5-acetoxyisoxazolidines. Therefore, the cycloaddition of the chiral nitrones 2-8 with vinyl acetate was investigated. The reaction of the nitrone 9 with vinyl acetate has been described by Merino et al. ${ }^{16}$ It is known that 1,3-dipolar cycloadditions of electron-rich alkenes to chiral $\alpha$-alkoxy nitrones give preferentially antiadducts as a result of dipolarophile attack from the less sterically hindered si diastereotopic face of the nitrone. 9,16 
<smiles>CO[C@H]1OC(/C=[N+](/[O-])Cc2ccccc2)[C@H]2OC(C)(C)O[C@H]12</smiles>

3<smiles>[B][C@H]1C[C@@H]([C@H]2O[C@H](OC)C3OC(C)(C)O[C@@H]32)N(Cc2ccccc2)O1</smiles>

22

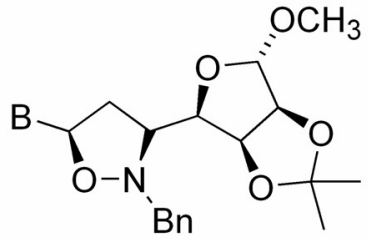

24<smiles>[B]C1C[C@H](C2O[C@H](OC)C3OC(C)(C)O[C@@H]32)N(Cc2ccccc2)O1</smiles>

23<smiles>[B]C1CC([C@H]2O[C@H](OC)C3OC(C)(C)O[C@@H]32)N(Cc2ccccc2)O1</smiles>

25

\section{Scheme 5}

\subsection{1,3-Dipolar cycloaddition of D-glycero nitrone with vinyl acetate}

The cycloaddition of 9 with vinyl acetate took place without solvent to give a mixture of four stereoisomeric isoxazolidines $\mathbf{2 6 a}-\mathbf{2 6 d}$ in an isomer ratio of 64:18:9:9 and a combined yield of $94 \%$ (Scheme 6). ${ }^{16}$

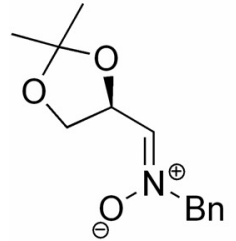

9<smiles>CC(C)(C)OC1CC([C@H]2COC(C)(C)O2)N(Cc2ccccc2)O1</smiles>

26a<smiles>CC(C)(C)O[C@@H]1C[C@@H]([C@@H]2COC(C)(C)O2)N(Cc2ccccc2)O1</smiles>

26c
$\mathrm{Bn}$<smiles>CC(C)(C)O[C@@H]1C[C@@H]([C@H]2COC(C)(C)O2)N(Cc2ccccc2)O1</smiles>

26b reflux, $20 \mathrm{~h}, 94 \%$

(26a:26b:26c:26d = 64:18:9:9)<smiles>CC(=O)OC1C[C@H]([C@H]2COC(C)(C)O2)N(Cc2ccccc2)O1</smiles>

26d

\section{Scheme 6}

\subsection{1,3-Dipolar cycloaddition of sugar- derived nitrones $2-8$ with vinyl acetate}

The 1,3-dipolar cycloaddition of the D-xylo nitrones $\mathbf{2 a}$ and $\mathbf{2} \mathbf{b}$ with vinyl acetate at reflux leads to the 5-acetoxy- substituted isoxazolidines as a mixture of diastereoisomers $\mathbf{2 7 a - d}$ and 28a,b,d respectively (Scheme 7). ${ }^{34}$ In contrast to the cycloadditions of these nitrones with vinylated

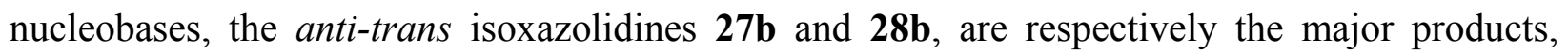


(entries 1,2, Table 1). The attack of the dipolarophile on the $Z$ configuration of the nitrones 2a-c proceeded preferentially through an endo transition state (Fig. $2, \mathrm{R}^{2}=\mathrm{OAc}$ ). The activation energy of the possible $Z / E$ - isomerization for the sugar- derived nitrones is too high and therefore the nitrones reacted without any isomerization. ${ }^{21,22} 4-O$-Benzyl- substituted D-xylo nitrone 2c reacted smoothly in vinyl acetate at reflux over $24 \mathrm{~h}$ to give an 83:10:7 mixture of the diastereoisomeric isoxazolidines 29a, 29b and 29d in $85 \%$ yield (entry 3, Table 1). ${ }^{35}$ The cycloaddition proceeded with very good diastereoselectivity for the anti-trans isoxazolidine 29b and is completely regioselective, with only the sterically favored 5-substituted isoxazolidines being detected.

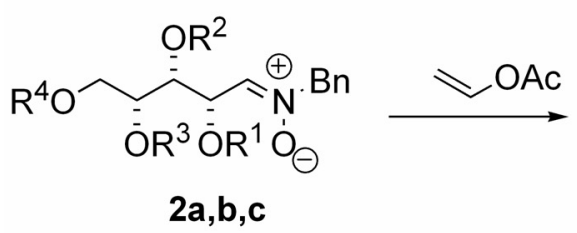

2a $R^{1}, R^{2}=R^{3}, R^{4}=\mathrm{CMe}_{2}$

2b $R^{1}, R^{2}=\mathrm{CMe}_{2}, R^{3}=B z, R^{4}=$ TBDPS

2c $R^{1}, R^{2}=\mathrm{CMe}_{2}, \mathrm{R}^{3}=\mathrm{Bn}, \mathrm{R}^{4}=$ TBDPS

$27 \mathrm{R}^{1}, \mathrm{R}^{2}=\mathrm{R}^{3}, \mathrm{R}^{4}=\mathrm{CMe}_{2}$

$28 R^{1}, R^{2}=\mathrm{CMe}_{2}, R^{3}=\mathrm{Bz}, \mathrm{R}^{4}=$ TBDPS

$29 \mathrm{R}^{1}, \mathrm{R}^{2}=\mathrm{CMe}_{2}, \mathrm{R}^{3}=\mathrm{Bn}, \mathrm{R}^{4}=\mathrm{TBDPS}$

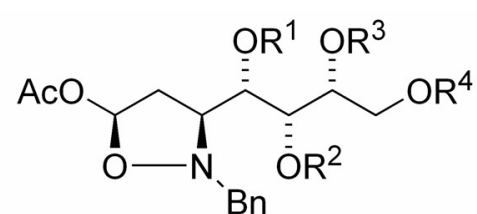

$27 a-29 a$

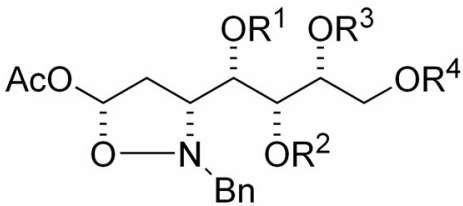

$27 c-29 c$

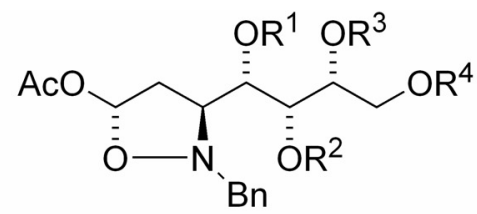

27b-29b

\section{Scheme 7}

Table 1. 1,3-Dipolar cycloaddition of nitrones 2-8 with vinyl acetate

\begin{tabular}{ccccccc}
\hline Entry & Nitrone & $\begin{array}{c}\text { Yield } \\
(\%)\end{array}$ & $\begin{array}{c}\text { anti-cis } \\
\mathbf{a}\end{array}$ & $\begin{array}{c}\text { anti-trans } \\
\mathbf{b}\end{array}$ & $\begin{array}{c}\text { syn-cis } \\
\mathbf{c}\end{array}$ & $\begin{array}{c}\text { syn-trans } \\
\mathbf{d}\end{array}$ \\
\hline 1 & $\mathbf{2 a}$ & 90 & 9 & 70 & 8 & 13 \\
2 & $\mathbf{2 b}$ & 73 & 14 & 71 & - & 15 \\
3 & $\mathbf{2 c}$ & 74 & 10 & 83 & - & 7 \\
4 & $\mathbf{3}$ & 86 & 47 & 21 & 18 & 14 \\
5 & $\mathbf{4}$ & 78 & 28 & 56 & 16 & - \\
6 & $\mathbf{5}$ & 68 & 84 & 16 & - & - \\
7 & $\mathbf{6}$ & 66 & 56 & 16 & 15 & 13 \\
8 & $\mathbf{7}$ & 73 & 51 & 18 & 17 & 14 \\
9 & $\mathbf{8}$ & 88 & 78 & 9 & 7 & 6 \\
\hline
\end{tabular}


On the other hand, cycloaddition of nitrone 3 with vinyl acetate afforded a mixture of four diastereoisomers 30a-d in $86 \%$ yield in favor of the major isomer 30a possessing the anti-cis configuration (Scheme 8 , entry 4 , Table 1$)^{33}$

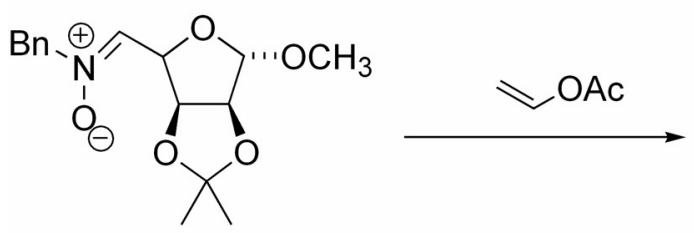

3

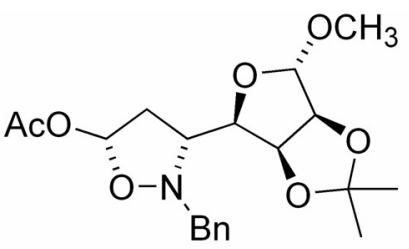

$30 a$

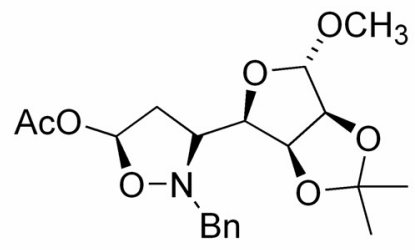

30c<smiles>CO[C@H]1CC([C@H]2C[C@H](OC(C)C)ON2Cc2ccccc2)[C@H]2OC(C)(C)O[C@H]12</smiles>

$30 \mathbf{b}$

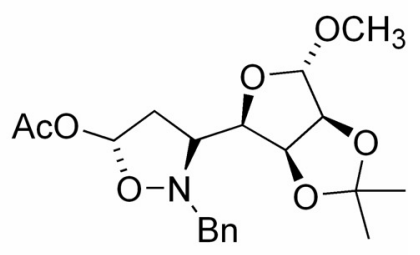

$30 \mathrm{~d}$

\section{Scheme 8}

The D-erythro nitrone 4, prepared starting from D-glucose, reacted smoothly in refluxing vinyl acetate over $20 \mathrm{~h}$ to give a 56:28:16 mixture of diastereoisomeric isoxazolidines 31a, 31b and 31d in $78 \%$ yield (Scheme 9). ${ }^{36}$ The cycloaddition proceeded with very good anti-facial (84:16) and endo-facial (72:28) diastereoselectivity (entry 5, Table 1). It is noteworthy that in this case the reaction — probably for steric reasons - proceeded with reversed diastereoselectivity as expected for an inverse-demand cycloaddition reaction where the corresponding 3,5-cis-adducts are the major products. ${ }^{9,16}$ The structure of the major diastereomer as anti-trans-31b was established unambiguously by X-ray diffraction studies. ${ }^{36}$

On the other hand, the reaction of the D-threo nitrone 5, prepared starting from D-galactose, with vinyl acetate proceeded diastereoselectively and gave only two diastereoisomers 32a and 32b in a 84:16 ratio, with anti-cis 32a being predominant - although four diastereoisomers are possible - showing now a preference for exo- attack, as expected for an inverse-demand cycloaddition reaction (Scheme 3). ${ }^{9,16}$ Moreover, in this case an excellent anti-diastereofacial induction was observed; the corresponding syn-adducts have not been detected in the reaction mixture (entry 5, Table 1). The structure of the minor trans-anti isoxazolidine $\mathbf{3 2 b}$ was established unambiguously by X-ray diffraction studies. ${ }^{36}$ Thus, the observed excellent facial diastereoselectivity for the D-galactose- derived nitrone $\mathbf{5}$ is in contrast with the afore- mentioned results obtained by the nitrone cycloadditions to vinyl acetate. 

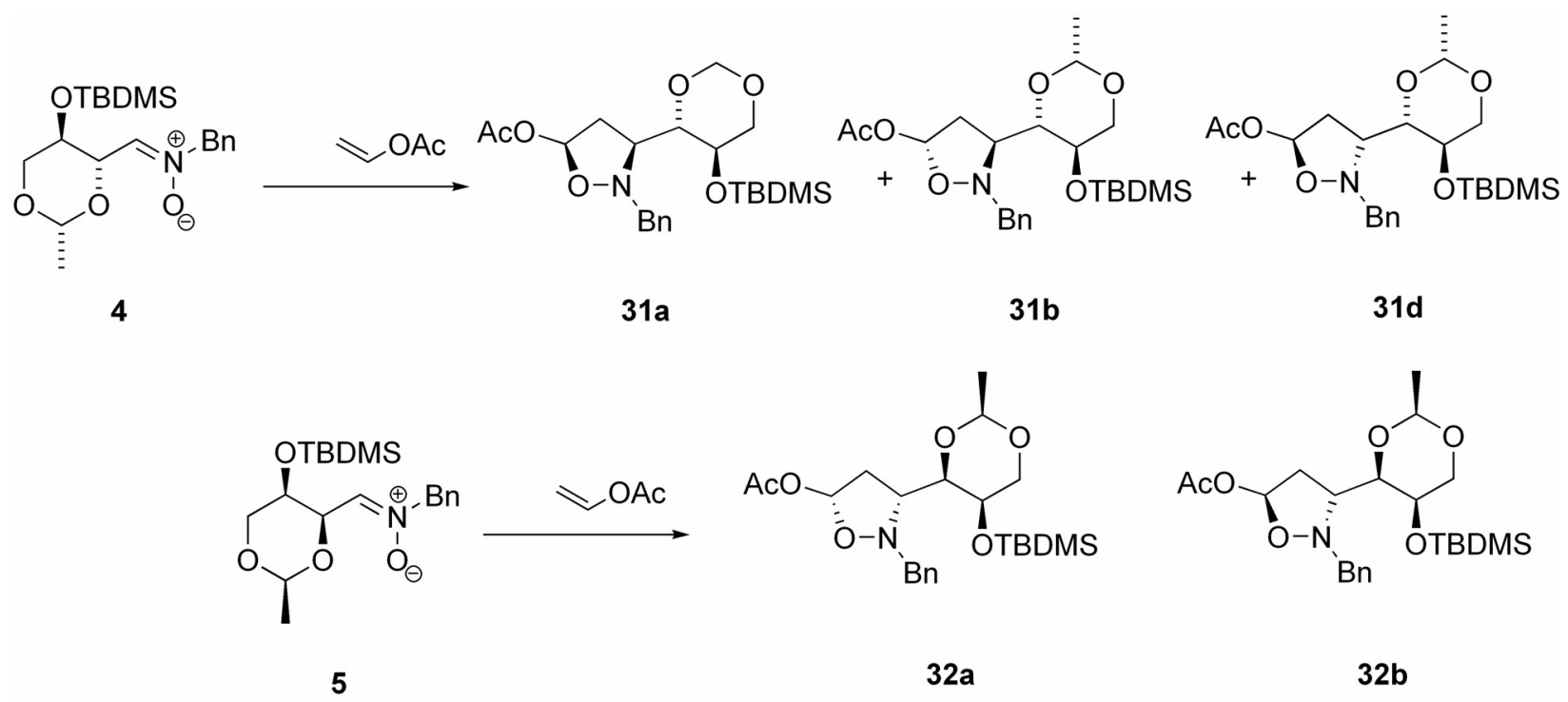

\section{Scheme 9}

The D-erythrose- derived nitrone 6, prepared starting from D-iso-ascorbic acid and the diastereomeric L-threose- derived nitrone 7 synthesized from L-ascorbic acid, reacted smoothly in refluxing vinyl acetate over $20 \mathrm{~h}$ to give a mixture of all possible 3,5-disubstituteddiastereoisomeric isoxazolidines 33a-d and 34a-d, respectively (Scheme 10). ${ }^{37}$ The major isomers 33a and 34a, possessing a C-1'/C-3 anti- relationship result from a dipolarophile attack from the sterically less hindered face of nitrone 6 and 7, respectively (entry 7 and 8, Table 1). The cycloaddition of the D-glyceraldehyde- derived nitrone 8 (Scheme 10) to vinyl acetate proceeded analogously, with good diastereoselectivity in favor of anti-cis isoxazolidine 35a, to give a mixture of diastereoisomers in the ratio 78:9:7:6 in 88\% yield. (entry 9, Table 1). ${ }^{37}$

\section{Isoxazolidinyl Nucleosides prepared by Vorbrüggen Nucleosidation}

In this Section, we describe syntheses of the modified isoxazolidinyl nucleosides from acetoxyisoxazolidines by Vorbrüggen nucleosidation. ${ }^{38,39}$ The condensation of the acetoxyisoxazolidines synthesized from D-glycero-, D-lyxo-, D-xylo-, D-erythro-, D-threo- and Lthreo- derived nitrones with silylated -uracil, -thymine, -cytosine, $-N$-acetylcytosine, $-N$ acetylguanine and -purines proceeded with good yields and with moderate to good stereoselectivity with formation of the isoxazolidinyl $\beta$ - and $\alpha$-nucleosides. We have made the potentially useful observation that the anomeric distribution of the formed nucleosides may be dependent not just on the nature of the attacking nucleobase but also on the 3 -substituent of the isoxazolidine. ${ }^{35-37}$ This observation might be exploited in future to allow the generation of anomerically pure nucleosides via the Vorbrüggen method. 
<smiles>C=CO[R16](=O)OCC</smiles>

6<smiles>[CH2+][C@H]1ON(Cc2ccccc2)[C@H](OC(C)(C)C)CC1[C@H](O[PbH3])[C@H]1COC(C)(C)O1</smiles>

$33 a$<smiles>CC(=O)O[C@H]1C[C@@H]([C@H](O[PbH3])[C@H]2COC(C)(C)O2)N(Cc2ccccc2)O1</smiles>

$33 c$<smiles>CC(=O)OC1CC([C@H](O[Pb])[C@@H]2COC(C)(C)O2)[C@@H]([OH2+])ON1Cc1ccccc1</smiles>

$34 a$<smiles>CC(=O)O[C@@H]1C[C@@H]([C@H](O[PbH3])[C@@H]2COC(C)(C)O2)[C@H](Cc2ccccc2)O1</smiles>

$34 c$<smiles>CC(=O)O[C@H]1C[C@@H]([C@H](O[PbH3])[C@H]2COC(C)(C)O2)N(Cc2ccccc2)O1</smiles>

33d

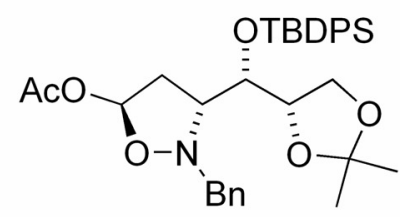

34d

reflux, $20 \mathrm{~h}$<smiles>COC1(C)O[C@H](/C=[N+](/[O-])Cc2ccccc2)CO[C@@]1(C)OC</smiles>

8<smiles>CO[C@H](C)O[C@H]1C[C@@H]([C@H]2CO[C@](C)(OC)[C@](C)(OC)O2)ON1Cc1ccccc1</smiles>

$35 a$

\section{Scheme 10}

\subsection{Isoxazolidinyl nucleosides derived from D-glyceraldehyde}

Merino and his colleagues have described the transformation of a mixture of anti- adducts 26a/26b into isoxazolidinyl- nucleoside analogues as depicted in Scheme $11{ }^{16}$ The condensation of a mixture of $\mathbf{2 6 \mathbf { a }}$ and $\mathbf{2 6 \mathbf { b }}$ with silylated thymine, using the glycosylation methodology developed by Vorbrüggen, ${ }^{38,39}$ resulted in a nucleoside product consisting of cis-36b and trans37b isomers (75:25) which were isolated in $80 \%$ combined yield. 
<smiles>CC(=O)Oc1ncc(C)c(O[As](C)(=O)=O)n1</smiles>

26a,26b<smiles>[B]C1CC([C@@H]2COC(C)(C)O2)N(Cc2ccccc2)O1</smiles>

$36 a-c$

$37 a-c$<smiles>O=c1cc[nH]c(=O)[nH]1</smiles>

a<smiles></smiles>

b<smiles></smiles>

C

\section{Scheme 11}

Zhao and his coworkers have obtained cis- 36b and trans- 37b isomers in a 94:6 ratio in 83\% combined yield. ${ }^{40}$ Condensation of acetate $26 \mathbf{a}$ with silylated uracil and $N$-benzoylcytosine in acetonitrile at room temperature, using TMSOTf as Lewis acid afforded the $\beta$-anomers 36a,c with excellent stereoselectivity (95:5). The acetoxy-isoxazolidine 26a was prepared in this case by Michael addition of $N$-methyl hydroxylamine to the $\alpha, \beta$-unsaturated ester derived from 2,3-O-isopropylidene-D-glyceraldehyde, followed by reduction with DIBAL and subsequent acetylation.

\subsection{Isoxazolidinyl nucleosides derived from D-xylose}

In contrast to other papers dealing with the condensation of a mixture of acetoxy- substituted isoxazolidines ${ }^{16}$ with silylated nucleobases by the Vorbrüggen method, we have always used the major diastereomerically pure 5-acetoxy- substituted isoxazolidines. ${ }^{33,35-37}$ The anti-trans isoxazolidine $\mathbf{2 7} \mathbf{b}$ prepared by the 1,3-dipolar cycloaddition of nitrone $\mathbf{2 a}$ with vinyl acetate was coupled with silylated nucleobases according to the Vorbrüggen methodology. ${ }^{38,39}$ The condensation of $\mathbf{2 7 \mathbf { b }}$ with silylated uracil, thymine, cytosine or $N$-acetylcytosine at $70{ }^{\circ} \mathrm{C}$, in the presence of trimethylsilyl triflate as catalyst, proceeded with low (uracil, thymine) - to good (cytosine or $N$-acetylcytosine) - yields and moderate stereoselectivity, with formation of the expected isoxazolidinyl $\beta$ - and $\alpha$-nucleosides $(38 \mathbf{a} / 39 \mathbf{a}$ ratio $63: 37, \mathbf{3 8 b} / \mathbf{3 9 b}$ ratio $63: 37, \mathbf{3 8 c} / 39 \mathrm{c}$ ratio $55: 45, \mathbf{3 8 d} / \mathbf{3 9 d}$ ratio $66: 34$, Scheme 12 ). The $\beta$-anomers 38a-d predominate, but significant amounts of $\alpha$-anomers 39a-d were obtained. These results are fully in accord with the data obtained for related Vorbrüggen nucleosidations. ${ }^{15-20}$ 


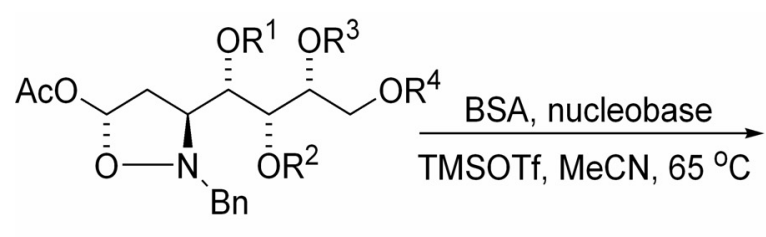

$27 b$

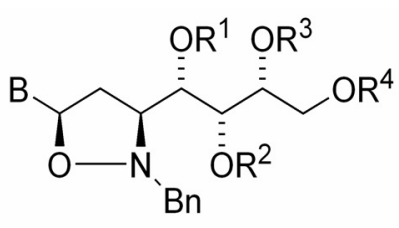

$38 a-d$

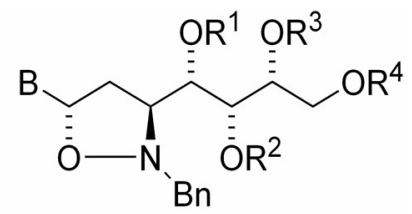

39a-d

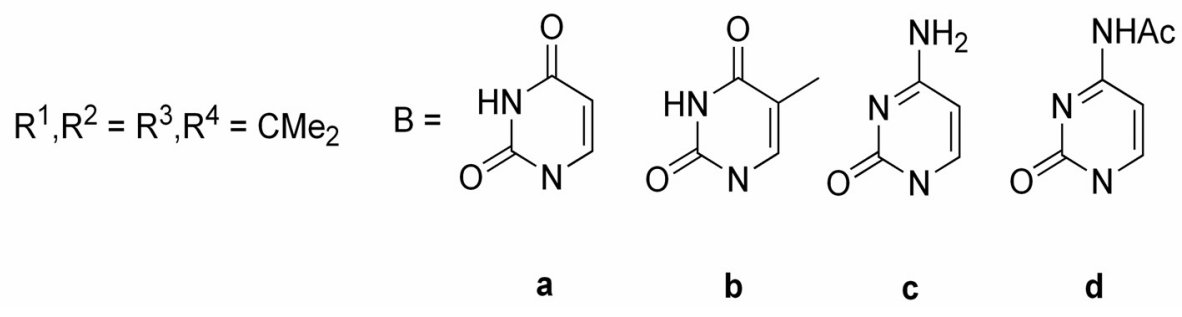

\section{Scheme 12}

A surprising and unexpected fact is that, in the case of the anti-trans-5-acetoxy- substituted isoxazolidine $\mathbf{2 8 b}$, prepared by the 1,3-dipolar cycloaddition of nitrone $\mathbf{2} \mathbf{b}$ with vinyl acetate, the Vorbrüggen nucleosidations with silylated nucleobases proceeded at $65{ }^{\circ} \mathrm{C}$ with excellent stereoselectivity. The corresponding $\beta$-anomers $\mathbf{4 0 a}, \mathbf{b}, \mathbf{d}$ are now the exclusive nucleosides for all of the used nucleobases (Scheme 13). ${ }^{35}$ The research groups of P. Merino, U. Chiacchio and R. Romeo have reported that the anomeric distribution obtained by Vorbrüggen nucleosidation with chiral 5-acetoxyisoxazolidines depends on the attacking nucleobase. ${ }^{2,41-43}$ The attack on the oxonium intermediate from either the $\alpha$ - or $\beta$-side is possible, and hence the product distribution is sensitive to structural changes of the reactants. In our case, the stereoselectivity of the addition of the silylated nucleobase is evidently more dependent on the structure of the substituent at C-3 originating from the starting chiral nitrone. Moreover, in this case the product of elimination, the corresponding isoxazoline derivative 42, was also isolated (Scheme 13). It is noteworthy that in the case of silylated 5-fluorouracil, the isoxazoline $\mathbf{4 2}$ is formed as the major product $(\mathbf{4 0 a} / \mathbf{4 2}$ ratio $58: 42, \mathbf{4 0 b} / \mathbf{4 2}$ ratio $81: 19, \mathbf{4 0 d} / \mathbf{4 2}$ ratio $90: 10, \mathbf{4 0 f} / \mathbf{4 2}$ ratio 9:91). To the best of our knowledge, such a formation of 2,3-dihydro-isoxazoles by the Vorbrüggen nucleosidation has not been observed. 2,3-Dihydro-isoxazoles represent a class of heterocycles that may be employed as useful building blocks for synthesis. ${ }^{44,45}$ 


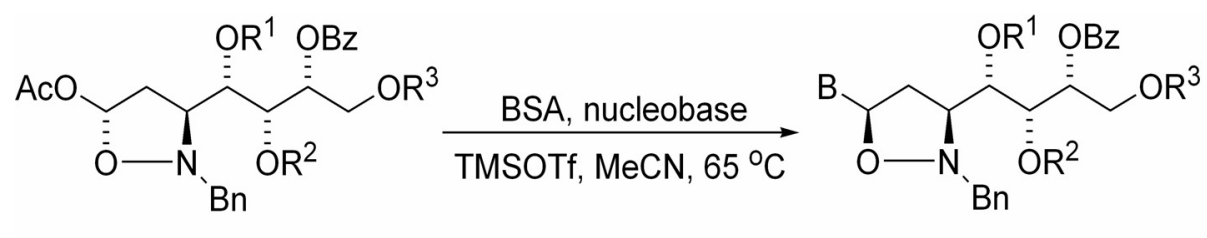

$28 b$
$\mathrm{R}^{1}, \mathrm{R}^{2}=\mathrm{CMe}_{2}, \mathrm{R}^{3}=$ TBDPS

$40 a, b, d-f$

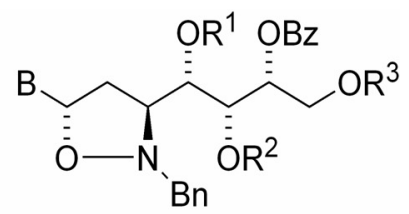

41a,b,d-f<smiles></smiles>

a<smiles></smiles>

b<smiles>CCCNc1cc[nH]c(=O)n1</smiles>

d

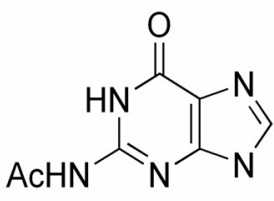

e<smiles></smiles>

f<smiles>[R20]CC([R20])C([R20])[C@H](O[R10])[C@H]1C=CON1Cc1ccccc1</smiles>

42

\section{Scheme 13}

We suppose that the isoxazoline $\mathbf{4 2}$ is formed by the elimination of the corresponding $\alpha$ anomers 41a,b and 41d. Therefore, we next studied the Vorbrüggen nucleosidation in methylene chloride at room temperature. Indeed, the product of elimination $\mathbf{4 2}$ was not detected, and both $\beta$ and $\alpha$-anomeric isoxazolidinyl nucleosides $\mathbf{4 0}$ and $\mathbf{4 1}$ were formed with high stereoselectivities in favor of the $\beta$-anomers 40 (40a/41a ratio 95:5, 40b/41b ratio 80:20, $\mathbf{4 0 d} / \mathbf{4 1 d}$ ratio 83:17, 40e/41e ratio 70:30, Scheme 13). Also, the first successful isoxazolidinyl nucleosides $40 \mathrm{e}$ and 41e derived from $N$-acetylguanine were obtained.

As has already been mentioned, the best stereoselectivity in the nucleosidation was achieved

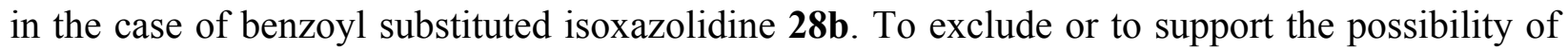
the participation of the neighboring benzoyl group, we have prepared the corresponding Dxylose- derived benzyl- substituted nitrone 2c. The Vorbrüggen nucleosidation of anti-trans benzyloxy- substituted isoxazolidine 29b with silylated uracil, thymine, $N$-acetylcytosine and guanine at RT in methylene chloride in the presence of trimethylsilyl triflate as catalyst, afforded the $\beta$-anomeric nucleosides $\mathbf{4 3}$ with the best diastereoselectivities in this series. Uracil and acetylated cytosine reacted with $90 \%$ diastereomeric excess $(\mathbf{4 3 a} / \mathbf{4 4 a}$ ratio $95: 5, \mathbf{4 3 b} / \mathbf{4 4 b}$ ratio $80: 20, \mathbf{4 3 d} / \mathbf{4 4 d}$ ratio $94: 6, \mathbf{4 3 e} / \mathbf{4 4 e}$ ratio $63: 37$, Scheme 14$)$. 


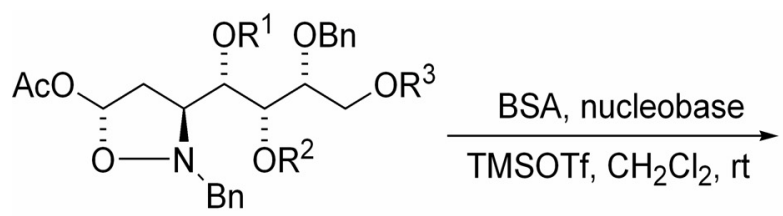

$29 b$

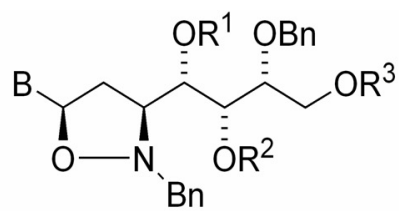

43a,b,d,e

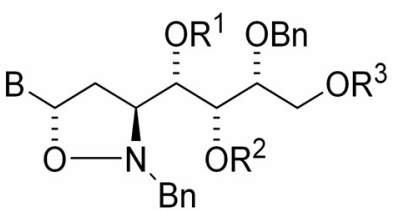

44a,b,d,e

$$
\mathrm{R}^{1}, \mathrm{R}^{2}=\mathrm{CMe}_{2}, \mathrm{R}^{3}=\text { TBDPS }
$$<smiles>O=c1cc[nH]c(=O)[nH]1</smiles>

a<smiles>Cc1c[nH]c(=O)[nH]c1=O</smiles>

b

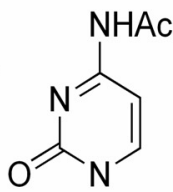

d<smiles>CCNc1nc2[nH]cnc2c(=O)[nH]1</smiles>

e

\section{Scheme 14}

\subsection{Isoxazolidinyl nucleosides derived from D-lyxose}

The condensation of the anti-cis isoxazolidine 30a derived from D-lyxose with silylated uracil, thymine and $\mathrm{N}$-acetylcytosine at $65{ }^{\circ} \mathrm{C}$ in the presence of 0.4 equiv. of trimethylsilyl triflate as catalyst, proceeded with good yields and from moderate- to good stereoselectivity under the formation of the expected isoxazolidinyl $\beta$ - and $\alpha$-nucleosides $(\mathbf{4 5 a} / \mathbf{4 6 a}$ ratio $67: 33, \mathbf{4 5 b} / \mathbf{4 6 b}$ ratio $88: 12, \mathbf{4 5 c} / \mathbf{4 6} \mathbf{c}$ ratio $80: 20$, Scheme 15$).{ }^{33}$ For $N$-acetylcytosine and thymine, the $\beta$-anomers clearly predominate, while in the case of uracil a significant amount of $\alpha$-anomer has been obtained.

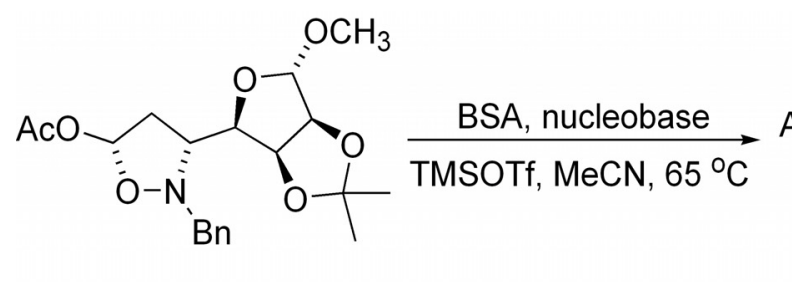

$30 a$<smiles>CO[C@H]1CC(C2O[C@@H](OC)C3OC(C)(C)OC23)N(Cc2ccccc2)O1</smiles>

$45 a-c$<smiles>CO[C@H]1OC(C2CC(OC(C)C)ON2Cc2ccccc2)C2OC(C)(C)O[C@H]21</smiles>

46a-c<smiles></smiles>

a<smiles>Cc1c[nH]c(=O)[nH]c1=O</smiles><smiles>CCCCNc1cc[nH]c(=O)n1</smiles>

b
C

\section{Scheme 15}




\subsection{Isoxazolidinyl nucleosides derived from D-erythrose}

Following extensive screening, we found the best reaction conditions for the Vorbrüggen nucleosidation of acetoxy- substituted isoxazolidines prepared from sugar- derived nitrones to be at RT in methylene chloride. ${ }^{35}$ The nucleosidation of the anti-trans isoxazolidine $\mathbf{3 1 b}$ with silylated uracil, thymine and $\mathrm{N}$-acetylcytosine at RT in methylene chloride in the presence of trimethylsilyl triflate as catalyst, afforded the mixture of anomeric nucleosides $47 \mathbf{a}-\mathbf{c}$ in moderate yields (65-66\%), but with excellent diastereoselectivities $(\mathbf{4 7 a} / \mathbf{4 8 a}$ ratio $92: 8, \mathbf{4 7} \mathbf{b} / \mathbf{4 8 b}$ ratio $90: 10,47 \mathbf{c} / 48 c$ ratio $94: 6$, Scheme 16). ${ }^{36}$ However, the reaction with $N$-acetylguanine gave a lower yield (36\%) and the diastereoselectivity was only moderate $(\mathbf{4 7 d} / \mathbf{4 8 d}$ ratio 69:31).

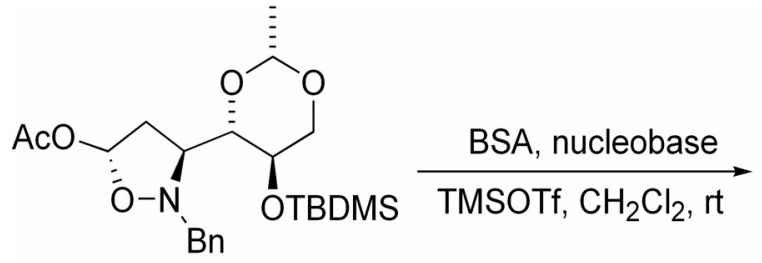

31b

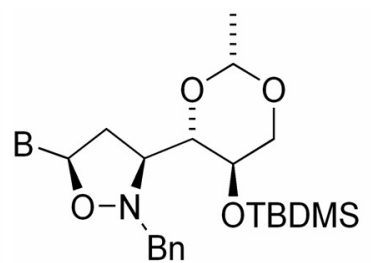

47a-d

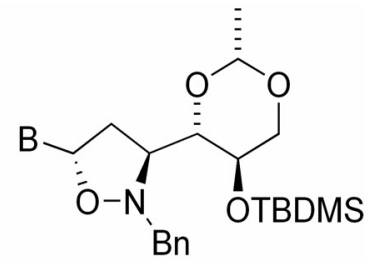

48a-d

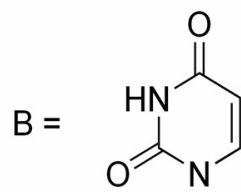

a<smiles>Cc1c[nH]c(=O)[nH]c1=O</smiles>

b<smiles></smiles>

C<smiles>O=c1[nH]c(NC2CC2)nc2[nH]cnc12</smiles>

d

\section{Scheme 16}

\subsection{Isoxazolidinyl nucleosides derived from D-threose}

The Vorbrüggen nucleosidation of the anti-cis isoxazolidine 32a with silylated uracil, thymine, $\mathrm{N}$-acetylcytosine, acetylguanine, 6-chloro- or 6-bromopurine at RT in methylene chloride in the presence of trimethylsilyl triflate as catalyst, proceeded with low (purines) to good (uracil, thymine and $\mathrm{N}$-acetylcytosine) yields, and from moderate to good stereoselectivity with the formation of the expected isoxazolidinyl $\beta$ - and $\alpha$-nucleosides 49 and 50 (49a/50a ratio 91:9, $\mathbf{4 9 b} / \mathbf{5 0 b}$ ratio $73: 27, \mathbf{4 9 c} / \mathbf{5 0 c}$ ratio $87: 13, \mathbf{4 9 d} / \mathbf{5 0 d}$ ratio $52: 48, \mathbf{4 9} / \mathbf{5 0 e}$ ratio $70: 30, \mathbf{4 9 f} / \mathbf{5 0 f}$ ratio 66:34, Scheme 17). ${ }^{36}$ For uracil and $N$-acetylcytosine, the $\beta$-anomers 49 clearly predominate, while in the case of $N$-acetylguanine and purines a significant amount of $\alpha$-anomer $\mathbf{5 0}$ has been obtained. This lower diastereoselectivity is in contrast with the excellent diastereoselectivity observed for anti-trans isoxazolidine 31b derived from D-erythrose, but these results are fully in accord with the data obtained for the related Vorbrüggen nucleosidations. ${ }^{15-20}$ 


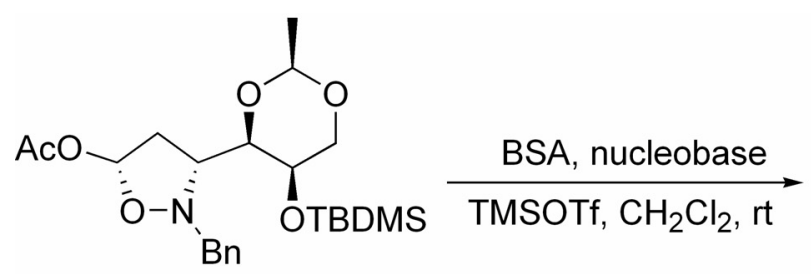

$32 a$<smiles>[B][C@H]1C[C@@H]([C@H]2OC(C)OC[C@H]2OC(C)(C)C)[C@H](O)O1</smiles>

49a-f

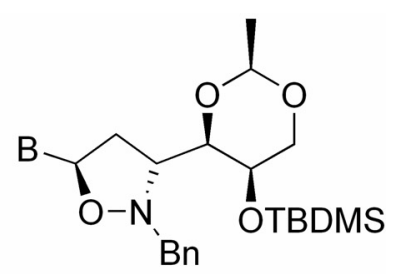

$50 a-f$<smiles></smiles>

a<smiles></smiles>

b<smiles>O=C(Nc1cc[nH]c(=O)n1)c1ccccc1</smiles>

c<smiles>CC(C)Nc1nc2[nH]cnc2c(=O)[nH]1</smiles>

d<smiles>Clc1ncnc2[nH]cnc12</smiles>

e<smiles>Brc1ncnc2[nH]cnc12</smiles>

f

\section{Scheme 17}

\subsection{Isoxazolidinyl nucleosides prepared from D-iso-ascorbic acid}

The nucleosidation of anti-cis isoxazolidine 33a derived from D-erythrose with silylated uracil, thymine, $\mathrm{N}$-acetylcytosine or $\mathrm{N}$-acetylguanine in the presence of trimethylsilyl triflate as catalyst, afforded the expected $\beta$-anomeric nucleosides 51a-d in low yields (20-48\%) for all of the used nucleobases (Scheme 18). ${ }^{37}$ The corresponding $\alpha$-anomeric nucleosides 52a-d were not detected in the reaction mixture. Moreover, and surprisingly, the major product - the 5-hydroxysubstituted isoxazolidine $53(35-60 \%)$ from all these reactions - does not contain the corresponding nucleobase. To the best of our knowledge, this kind of product of the TMSOTfcatalyzed hydrolysis of acetal moieties of the starting acetoxyisoxazolidine has not been observed in related Vorbrüggen nucleosidations. ${ }^{15-20}$

\subsection{Isoxazolidinyl nucleosides derived from L-threose}

Gratifyingly, the nucleosidation of the anti-cis isoxazolidine 34a, derived from L-threose with silylated uracil, - thymine or $N$-acetylcytosine in the presence of trimethylsilyl triflate as catalyst, afforded only the $\beta$-anomeric nucleosides 54a-c as single products in good yields (62-65\%). The corresponding $\alpha$-anomeric nucleosides 55a-c have not been detected in the reaction mixture (Scheme 19). ${ }^{37}$ This is the best observed diastereoselectivity for the nucleosidation of 5-acetoxysubstituted isoxazolidines achieved from sugar- derived nitrones. 


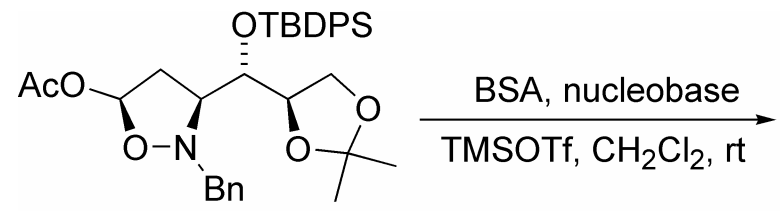

$33 a$

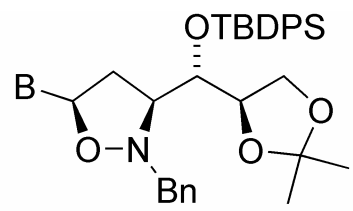

51a-d<smiles>OC[C@@H](O)[C@H](O[PbH2])[C@@H]1CC(O)ON1Cc1ccccc1</smiles>

53<smiles></smiles>

a<smiles></smiles>

b<smiles>O=c1nc(Nc2ccccc2)cc[nH]1</smiles>

C<smiles>CC(C)Nc1nc2[nH]cnc2c(=O)[nH]1</smiles>

d<smiles>CC1(C)OC[C@H]([C@H](O[Pb])[C@H]2CC(O[Ge])ON2Cc2ccccc2)O1</smiles>

52a-d

Scheme 18

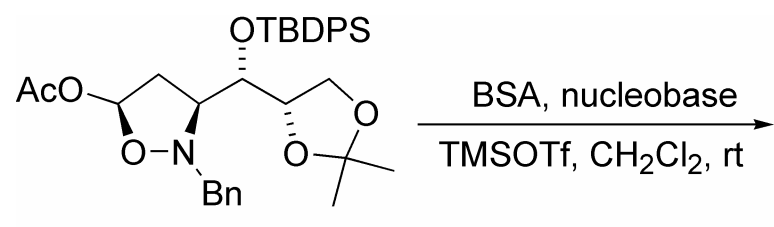

$34 a$<smiles>[B]C1CC([C@H](O[PbH3])[C@H]2COC(C)(C)O2)N(Cc2ccccc2)O1</smiles>

54a-c<smiles>[B][C@H]1CC([C@H](O[PbH3])[C@H]2COC(C)(C)O2)N(Cc2ccccc2)O1</smiles>

$55 a-c$<smiles></smiles>

a<smiles></smiles>

b<smiles>O=C(Nc1cc[nH]c(=O)n1)c1ccccc1</smiles>

c

\section{Scheme 19}

\subsection{Isoxazolidinyl nucleosides prepared from D-mannitol}

Finally, the nucleosidation of the anti-cis isoxazolidine 35a derived from protected Dglyceraldehyde, prepared starting from D-mannitol with silylated uracil, -thymine or $-N$ acetylcytosine in the presence of trimethylsilyl triflate as catalyst afforded the $\beta$-anomeric nucleosides 56a-c in good yields (62-87\%) and with high diastereoselectivities (56a/57a ratio $85: 15, \mathbf{5 6 b} / \mathbf{5 7 b}$ ratio $86: 14, \mathbf{5 6} \mathbf{c} / \mathbf{5 7} \mathbf{c}$ ratio $90: 10$, Scheme 20$){ }^{37}$ 


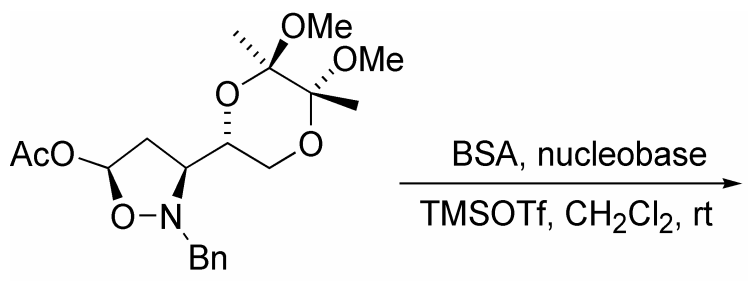

$35 a$<smiles>[B]C1C[C@H]([C@H]2CO[C@](C)(OC)[C@@](C)(OC)O2)N(Cc2ccccc2)O1</smiles>

56a-c<smiles>[B]C1C[C@H]([C@H]2CO[C@](C)(OC)[C@@](C)(OC)O2)N(Cc2ccccc2)O1</smiles>

57a-c<smiles></smiles>

a<smiles>Cc1c[nH]c(=O)[nH]c1=O</smiles>

b<smiles>O=C(Nc1cc[nH]c(=O)n1)c1ccccc1</smiles>

C

\section{Scheme 20}

\section{Conclusions}

From two strategies for the diastereoselective synthesis of isoxazolidinyl nucleosides a two-step methodology based on the Vorbrüggen nucleosidation of the 5-acetoxyisoxazolidines proceeded more selectively than a one-step approach based on the 1,3-dipolar cycloaddition of $C$-glycosyl nitrones with vinyl nucleobases. We have made the potentially useful observation that the anomeric distribution of the formed nucleosides may be dependent not just on the nature of the attacking nucleobase but also on the 3-substituent of the isoxazolidine. This observation might be exploited in future to allow the generation of anomerically pure nucleosides via the Vorbrüggen method.

\section{Acknowledgements}

The authors are grateful to the Slovak Grant Agency (No. 13549/06), APVV (No. 20/000305) and the Deutsche Forschungsgemeinschaft. The NMR experimental work was facilitated by the support of Slovak National Research (No 2003SP200280203).

\section{References and Footnotes}

1. Frederickson, M. Tetrahedron 1997, 53, 403.

2. Gothelf, K. V.; Jørgensen, K. A. Chem. Rev. 1998, 98, 863. 
3. Merino, P.; Franco, S.; Merchan, F. L.; Romero, P.; Tejero, T.; Uriel, T. S. Tetrahedron: Asymmetry 2003, 14, 3731.

4. Merino, P. In: Sciences of Synthesis; Padwa, A. Ed.; Thieme: Stuttgart, 2004; Vol. 27, p 511.

5. Osborn, H. M. I.; Gemmel, N.; Harwood, L. M. J. Chem. Soc., Perkin Trans. $12002,2419$.

6. Koumbis, A. E.; Gallos, J. K. Curr. Org. Chem. 2003, 7, 585.

7. Fišera, L.; Ondruš, V.; Kubán, J.; Micúch, P.; Blanáriková, I.; Jäger, V. J. Heterocyclic Chem. 2000, 37, 551.

8. Pellissier, H. Tetrahedron 2007, 63, 3235.

9. Fišera, L. In Topics in Heterocyclic Chemistry. Heterocycles from Carbohydrate Precursors, El Ashry, E. S. H., Ed.; Springer, 2007; p 287.

10. Merino, P. Compt. Rend. Chim. 2005, 8, 775.

11. De Clercq, E. Biochim. Biophys. Acta 2002, 258, 1587.

12. Merino, P. Curr. Med. Chem. Anti Infective Agents 2002, 1, 389.

13. Romeo, G.; Iannazzo, D.; Piperno, A.; Romeo, R.; Corsaro, A.; Rescifina, A.; Chiacchio, U. Mini-Rev. Org. Chem. 2005, 2, 59.

14. Merino, P.; Franco, S.; Merchan, F. L.; Tejero, T. Recent Research Development in Organic Chemistry 2000, 4, 227.

15. Chiacchio, U.; Corsaro, A.; Gumina, G.; Rescifina, A.; Iannazzo, D.; Piperno, A.; Romeo, G.; Romeo, R. J. Org. Chem. 1999, 64, 9321.

16. Merino, P.; Del Alamo, E. M.; Santiago, F.; Merchan, F. L.; Simon, A.; Tejero, T. Tetrahedron: Asymmetry 2000, 11, 1543.

17. Chiacchio, U.; Corsaro, A.; Iannazzo, D.; Pieperno, A.; Procopio, A.; Rescifina, A.; Romeo, G.; Romeo, R. Eur. J. Org. Chem. 2001, 1893.

18. Chiacchio, U.; Corsaro, A.; Iannazzo, D.; Piperno, A.; Pistara, V.; Procopio, A.; Rescifina, A.; Romeo, G.; Romeo, R.; Siciliano, M. C. R.; Valveri, E. ARKIVOC 2002, (xi), 159.

19. Colacino, E.; Converso, A.; Ligueri, A.; Napoli, A.; Siciliano, C.; Sindona, G. Tetrahedron 2001, 57, 8551.

20. Chiacchio, U.; Corsaro, A.; Iannazzo, D.; Piperno, A.; Pistara, V.; Rescifina, A.; Romeo, R.; Valveri, V.; Mastino, A.; Romeo, G. J. Med. Chem. 2003, 46, 3696.

21. Kubán, J.; Blanáriková, I.; Fišera, L; Jarošková, L.; Fengler-Veith, M.; Jäger, V.; Kožíšek, J.; Humpa, O.; Prónayová, N.; Langer, V. Tetrahedron 1999, 55, 9501.

22. Kubán, J.; Kolarovič, A.; Fišera, L.; Jäger, V.; Humpa, O.; Prónayová, N.; Ertl, P. Synlett 2001, 1862.

23. Kubán, J.; Kolarovič, A.; Fišera, L.; Jäger, V.; Humpa, O.; Prónayová, N. Synlett 2001, 1862.

24. Blanáriková-Hlobilová, I.; Kopaničáková, Z.; Fišera, L.; Cyrański, M. K.; Salanski, P.; Jurczak, J.; Prónayová, N. Tetrahedron 2003, 59, 3333.

25. Dugovič, B.; Wiesenganger, T.; Fišera, L.; Hametner, C.; Prónayová, N. Heterocycles 2005, 65,591 . 
26. Dugovič, B.; Fišera, L.; Cyranski, M. K.; Hametner, C.; Prónayová, N.; Obranec, M. Helv. Chim. Acta 2005, 88, 1432.

27. Rehák, J.; Fišera, L.; Kožíšek, J.; Perašínová, L.; Steiner, B.; Koóš, M. ARKIVOC 2008, (viii), 18.

28. Chiacchio, U.; Rescifina, A.; Corsaro, A.; Pistara, V.; Romeo, G.; Romeo, R. Tetrahedron Asymmetry 2000, 11, 2045.

29. Legio, A.; Liguori, A.; Procopio, A.; Siciliano, C.; Sindona, G. Tetrahedron Lett. 1996, 37, 1277.

30. Pan, S.; Amankulov, N. A.; Zhao, K. Tetrahedron 1998, 54, 6587.

31. Colacino, E.; Converso, A.; De Nino, A.; Leggio, A.; Liguori, A.; Maiuolo, L.; Napoli, A.; Procopio, A.; Siciliano, C.; Sindona, G. Nucleoside and Nucleotides 1999, 18, 581.

32. Fischer, R.; Drucková, A.; Fišera, L.; Rybár, A.; Hametner, C.; Cyrański, M. K. Synlett 2002, 1113.

33. Hýrošová, E.; Fišera, L.; Jame, R. M.-A.; Prónayová, N.; Medvecký, M.; Koóš, M. Chem. Heterocycl. Comp. 2007, 14.

34. Fischer, R.; Drucková, A.; Fišera, L.; Hametner, C. ARKIVOC 2002, (viii), 80.

35. Hýrošová, E.; Medvecký, M.; Fišera, L.; Hametner, C.; Fröhlich, H.; Marchetti, M.; Allmaier, G. Tetrahedron 2008, 64, 3111.

36. Hýrošová, E.; Fišera, L.; Kožíšek, J.; Fronc, M. Synthesis 2008, 1233.

37. Hýrošová, E.; Fišera, L.; Reissig, H.-U.; Al-Harrasi, A. Tetrahedron Asymmetry (submitted).

38. Vorbrüggen, H.; Krolikiewicz, K.; Bennua, B. Chem. Ber. 1981, 114, 1234.

39. Vorbrüggen, H.; Ruh-Pohlenz, C. In Organic Reactions, Synthesis of Nucleosides; Paquette, L., Ed.; J. Wiley and Sons, Inc.: New York, 2000; Vol. 55, p 1.

40. Xiang, Y.; Gi, H.-J.; Niu, D.; Schinazi, R. F.; Zhao, K. J. Org. Chem. 1997, 62, 7430.

41. Merino, P.; Franco, S.; Merchan, F. L.; Tejero, T. J. Org. Chem. 2000, 65, 5575.

42. Chiacchio, U.; Corsaro, A.; Iannazzo, D.; Piperno, A.; Pistara, V.; Rescifina, A.; Romeo, R.; Sindona, G.; Romeo, G. Tetrahedron: Asymmetry 2003, 14, 2717.

43. Chiacchio, U.; Iannazzo, D.; Piperno, A.; Romeo, R.; Romeo, G.; Rescifina, A.; Saglimbeni, M. Bioorg. Med. Chem. 2006, 14, 955.

44. DeShong, P.; Li, W.; Kennington, J.; Ammon, H. L. J. Org. Chem. 1991, 56, 1364.

45. Aschwanden, P.; Frantz, D. E.; Carreira, E. M. Org. Lett. 2000, 2, 2331. 